\title{
ANALISIS INTEGRASI SISTEM INFORMASI MANAJEMEN PUSKE SM AS DAN SIKDA GENERIK DENGAN METODE PRISM
}

\author{
A sih Prasetyowati \\ Dosen Prodi Rekam Medis dan Informasi Kesehatan ST IKE S HAKL I Semarang \\ dhicalove@gmail.com
}

\begin{abstract}
Analysis of HIS ( Health Information System) in Indonesia is still inadequate and needs to be improved. To decrease the problemof HIS, Indonesian government has formulated a vision which is build integrated heal th information system in 2014 through SI KDA Generikapplication. SI MPUS of Rembang need to be eval uated to answer themanagement needs and to knowhow SI MPUScan beintegrated with SI KDAGenerik. Thepurposeof this study was to determinewhether SI MPUS can integratewith SI KDA Generic by eval uating system SIMPUS analysis method used PRISM ( Performance Of Routinel nformation SystemManagement). This research isa casestudy at SI MPUS of Public Health Center of Kragan 2 Rembang with cross sectional approach. Analysis of the technical factors indicate that SIMPUS still limited to the reporting of di seases and patient visits ( LB1 and LB4 ) and has not included data from outside service activity. Analysis of the organization factors was found that there is no masterplan and resources are still limited. Analysis of the behavioral factors indicate that SIMPUS operators have the skills and competence sufficient to manage SIMPUS. Complexity SIMPUS was less support to increased motivation of operators. Analysis of SIMPUS integration with SIKDA Generik shows that there is still a gap of records and reports and that the differences concept between family and individual. Recommendations for SI MPUS development is the application of single patient identity, family and patient master index, query systems and data migration system Need a master plan and HIS Roadmap.
\end{abstract}

Keywords: Integration of information system management information system generic health information system, PRISM metode, public heal th center

\begin{abstract}
Abstrak
Pemerintah telah merumuskan visi sisteminformasi kesehatan yaitu terwujudnyaSisteml nformasi Kesehatan terintegrasi pada tahun 2014 melalui aplikasi SI KDA Generik. SIMPUS di puskesmas Kabupaten Rembang perlu dianal isis untuk menjawab pemenuhan kebutuhan integrasi dengan SIKDA Generik.Tujuan penelitian ini adal ah untuk mengetahui apakah SI M PUS dapatberintegrasi dengan SIKDA Generik. Metodeanal isisyang digunakan adal ah metodePRISM (Performanceof Routinel nformation SystemManagement). J enis penelitian ini adal ah studi kasusSI MPUS di Puskesmas Kragan 2 Kabupaten Rembang dengan pendekatan cross sectional. Hasil analisis pada faktor teknis menunjukkan bahwa SIMPUS masih terbatas pada pelaporan kesakitan dan kunjungan pasien (LB1 dan LB4) dan tidak terintegrasi dengan pelayanan luar gedung. Anal isis pada faktor organisasi didapatkan bahwa belum adamasterplan pembangunan SI MPUS sedangkan sumber daya terbatas. Analisis pada faktor perilaku menunjukkan bahwa pengelola SI MPUS telah memiliki ketrampilan dan kompetensi yang cukup untuk mengel ola SIMPUS tetapi kompleksitas sistem kurang mendukung motivasi pengelola. Anal isis integrasi SIMPUS dengan SIKDA Generik menunjukkan bahwa masih terdapat gap record dan report yaitu perbedaan konsep family dan individu. Rekomendasi pengembangan SIMPUS adalah penerapan singleidentitypasien, pengembangan family and patient master index, dengan sistem query dan migrasi data.Perlu adanya masterplan pengembangan SIMPUS yang disesuai kan dengan roadmap SI K.
\end{abstract}

Kata kunci: integrasi sistem informasi, sistem informasi manajemen, sistem informasi kesehatan generik, metode PRISM, puskesmas 
J urnal Manajemen I nformasi Kesehatan I ndonesia Vol . 4 No.2 Oktober 2016

ISSN: 2337-6007 (online); 2337-585X (Printed)

\section{PENDAHUL UAN}

Sistem Informasi Kesehatan di Indonesia masih terfragmentasi sehingga belum mampu menyediakan data dan informasi yang efektif bagi pembangunan kesehatan.Pemerintah telah merumuskan visi Sistem Informasi Kesehatan Indonesia yaitu terwujudnya Sistem Informasi Keschatan terintegrasi pada tahun 2014 (Depkes RI, 2009).Perkembangan teknologi informasi telah memungkinkan terwujudnya integrasi data kesehatan nasional melalui Bank Data Nasional. Kementerian Kesehatan melalui Pusat Data dan informasi saat ini telah membangun Aplikasi SIKDA Generik yang berisi dataset yang di harapkan menjadi sebuah standar pencatatan dan pelaporan setiap sarana kesehatan di seluruh Kota/Kabupaten (Kemenkes RI, 2011).

Implementasi SIMPUS di puskesmas-puskesmas Kabupaten Rembang telah dilakukan sejak tahun 2011 dan sampai saat ini belum dilakukan analisis sistem. Permasal ahanyang di temukan adalah SI MPUS hanya menyediakan input data pelayanan pasien untuk kebutuhan laporan LB1 (laporan kesakitan) dan LB4 (laporan kegiatan puskesmas). Pengelolaan laporan LB2 (laporan obat-obatan), LB3 (laporan gizi, KIA, imunisasi, dan pemberantasan penyakit) berbentuk paper based. Sistem pencatatan data masih dilakukan dua kali kerja yaitu entri SIMPUS dan pencatatan manual. Laporan kesakitan puskesmas induk dengan pustu masi h di rekap secara manual sehingga pel aporan seringkali mengalami keterlambatan. Maka di perlukan analisissistem secara lebih mendalam untuk menjadi landasan bagi pengembangan SIMPUS untukmemenuhi kebutuhan pengelolaan data kesehatan Kabupaten Rembang sekaligus mendukung integrasi SIKDA Generik. Analisis SIMPUS menggunakan Kerangka KejaPRISM yaitu Performanceof Routinelnformation SystemManagement. PRISM adalah pendekatan untuk merancang, memperkuat, dan menganal isis suatu sistem informasi kesehatan rutin. Kelancaran suatu proses pelaksanaan sistem di pengaruhi ol eh determinanteknis, organisasi, dan perilaku (Aqil, 2009). Tujuan penelitian ini adalah untuk mengetahui seberapa besarsistem informasi manajemen puskesmas di Puskesmas Kragan 2 Kabupaten Rembang dapat diintegrasikan dengan SIKDA Generik.

\section{METODE PENELITIAN}

Metode analisis SIMPUS yang digunakan adalah metodePRISM (Performance Of Routine Information SystemManagement). Jenis penelitianadalahstudi kasus
SI MPUS di Puskesmas Kragan 2 Kabupaten Rembang dengan pendekatan cross sectional (Yin, 2013). Variabel penelitian adalah faktor-faktor determinan dalam SIMPUS yaitu faktor teknis, organisasi, perilaku, kinerja SIMPUS, dan kompatibilitas SIKDA Generik. Pengumpulan data dengan wawancara mendalam(indept interview) dan observasi pada komponen-komponen SIMPUS. Datadianal isis secara kual itatif untuk mendapatkan kompati bilitas SIMPUS dengan SIKDA Generik.

\section{HASIL}

\section{K arakteristik R esponden}

Informan adal ah orang-orang yang terli bat langsung pada pengel olaan SIMPUS di Puskesmas Kragan 2. Karakteristik informan dapat dilihat pada tabel 1.

Tabel 1 Karakteristik Informan Berdasarkan Pendidikan

\begin{tabular}{|c|c|c|c|}
\hline INFORMAN & JABATAN & Pendidikan & Jumlah \\
\hline \multirow{5}{*}{$\begin{array}{l}\text { Informan } \\
\text { Utama }\end{array}$} & Operator SIMPUS & SMA & 1 orang \\
\hline & Operator SIMPUS & D3 & 1 orang \\
\hline & $\begin{array}{l}\text { Koordinator Rekam } \\
\text { Medis }\end{array}$ & D3 & 1 orang \\
\hline & KepalaTU & S1 & 1 orang \\
\hline & Kepala Puskesmas & S1 & 1 orang \\
\hline \multirow{3}{*}{$\begin{array}{l}\text { Informan } \\
\text { Triangul asi }\end{array}$} & Staf BidangYankesDKK & S1 & 1 orang \\
\hline & $\begin{array}{l}\text { Kepal a Bidang Yankes } \\
\text { DKK }\end{array}$ & $\mathrm{S} 1$ & 1 orang \\
\hline & $\begin{array}{l}\text { Kasie Pengembangan } \\
\text { SIK DKK }\end{array}$ & $\mathrm{S} 2$ & 1 orang \\
\hline
\end{tabular}

Informan dari puskesmas adalah pengel ola SIMPUS, kepala TU, dan kepala puskesmas dengan pendidikan minimal SMA. Informan triangulasi digunakan untuk mengecek kebenaran informasi dari informan utama. Informan triangulasi dipilih dari staf DKK yaitu Sie Pengembangan SIK DKK dn staf Bidang Pelayanan Kesehatan sebagai penerima laporan SI MPUS.

\section{G ambaran UmumSIM PUS}

Puskesmas Kragan 2 adalah pilot project pengembangan SIMPUS di Kabupaten Rembang. J umlah pasien terus mengalami peningkatan dari tahun ke tahun. Dasar pelaksanaan sistem informasi manajemen UPT Puskesmas Kragan I adalah SP2TP (Sistem Pencatatan dan Pelaporan Terpadu Puskesmas) berdasarkan K eputusan Dirjen Binkesmas No. 590/BM/DJ/INFON/96. SIMPUS mulai di bangun tahun 2011 dengan pengembangan awal mengcover pelayanan dalamgedung.Flowchart 
Asih Prasetyowati. Analisis Integrasi Sistem Informasi Manajemen Puskesmas dan Sikda ...

SIMPUS pada gambar 1 menunjukkan bahwa SIMPUS hanya mengcover pencatatan pelayanan dal am gedung. Petugas masih melakukan doble pencatatan manual dan elektronik di bagian pendaftaran. Administrasi masih merekap data untuk menggabungkan laporan puskesmas induk dan puskesmas pembantu. PengelolaSIMPUS terdiri dari 5 orang petugas, terdapat 2 buah PC client dan 1 buah PC server.

Flowchart SIMPUS pada gambar 1 menunjukkan bahwa SIMPUS hanya mengcover pencatatan pelayanan dalamgedung. Petugas masi h melakukan doble pencatatan manual dan elektronik di bagian pendaftaran. Administrasi masih merekap data untuk menggabungkan laporan puskesmas induk dan puskesmas pembantu. PengelolaSIMPUS terdi i dari 5 orang petugas, terdapat 2 buah PC client dan 1 buah PC server.

\section{G ambar 1 Flowchart SIM PUS}

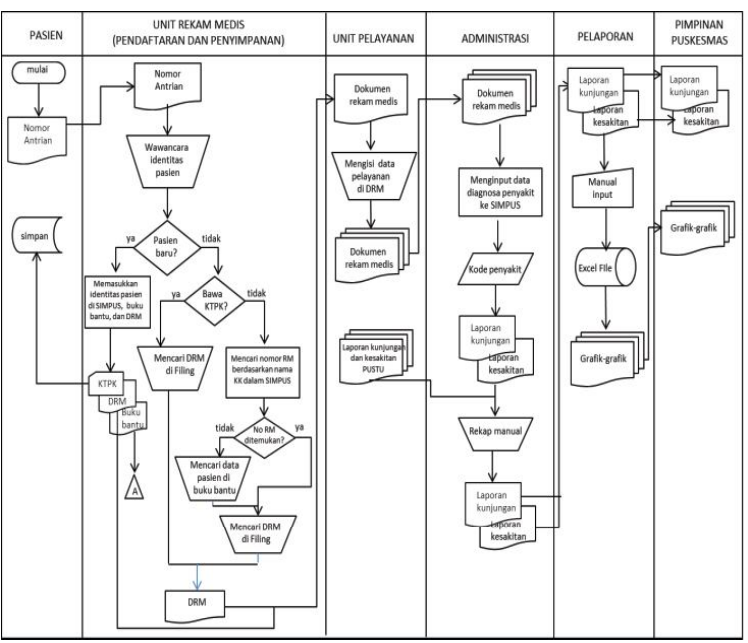

\section{A nalisisK ompatibilitas SIM PUS dengan SI K DA} Generik

Analisis kompatibilitas SIMPUS dengan SIKDA Generik dimaksudkan untuk memetakan komponenkomponen dan melihat persamaan dan perbedaan antara kedua sistem. Anal isis mel iputi taktor teknis, organisasi, dan perilaku seperti pada tabel berikut.

Tabel 2 K ompatibilitas Faktor Teknis SI M PUS dengan SIK DA G enerik

\begin{tabular}{|c|c|c|}
\hline SIMPUS & Gap & SIKDA Generik \\
\hline PUS & & Modul S \\
\hline & & Generik terdiri dari: \\
\hline $\begin{array}{l}\text { a. Pendaftaran } \\
\text { b. Pelayanan pasien }\end{array}$ & $\begin{array}{l}\text { Pedoman SIMPUS } \\
\text { terbatas pada pendaf- } \\
\text { taran dan pelayanan }\end{array}$ & $\begin{array}{l}\text { a. Modul pendaf- } \\
\text { taran }\end{array}$ \\
\hline
\end{tabular}

\begin{tabular}{|c|c|c|}
\hline $\begin{array}{l}\text { Pelaporan LB1 } \\
\text { dan LB4 }\end{array}$ & $\begin{array}{l}\text { pelayanan untuk } \\
\text { laporan LB } 1 \text { dan } \\
\text { LB4 }\end{array}$ & $\begin{array}{l}\text { b. Modul pelayanan } \\
\text { c. Modul apotik } \\
\text { d. M o d u I } \\
\text { Laboratorium } \\
\text { e. Modul Radiologi } \\
\text { f. Modul Rawat } \\
\text { Inap } \\
\text { y. Modul Kasir } \\
\text { h. Modul pelayanan } \\
\text { Iuar gedung } \\
\text { i. Modul Iaporan }\end{array}$ \\
\hline $\begin{array}{l}\text { Rancangan input } \\
\text { data: } \\
\text { d. Identitas pasien } \\
\text { berdasarkan ke- } \\
\text { Iompok family } \\
\text { b. Pencarian data } \\
\text { pasi en berda- } \\
\text { sarkan nama KK } \\
\text { c. Data pelayanan } \\
\text { pasientidak terin- } \\
\text { tegrasi dengan } \\
\text { biling, apotik, } \\
\text { Iaboratori um, } \\
\text { radi ol ogi dan } \\
\text { pelayanan Iuar } \\
\text { gedung }\end{array}$ & $\begin{array}{l}\text { Gap Kompl eksitas } \\
\text { Disain SIMPUS: } \\
\text { Di sain SI M PUS } \\
\text { berdasarkan konsep } \\
\text { tami ly sedangkan } \\
\text { SI KDA G eneri K } \\
\text { berdasarkan konsep } \\
\text { individu } \\
\text { D i sai n i n put } \\
\text { SIMPUS tidak ter- } \\
\text { integrasi dengan } \\
\text { pelayanan penunjang } \\
\text { dan pelayanan luar } \\
\text { gedung }\end{array}$ & $\begin{array}{l}\text { Rancangan input } \\
\text { data: } \\
\text { d. Data identitas } \\
\text { pasi en berda- } \\
\text { sarkan individu } \\
\text { b. Pencarian data } \\
\text { pasien berdasar- } \\
\text { kan nama pasien } \\
\text { c. Data pelayanan } \\
\text { pasienterintegrasi } \\
\text { dengan tarif, } \\
\text { Iaboratorium, } \\
\text { radiologi, ra- } \\
\text { wat inap, dan } \\
\text { pelayanan Iuar } \\
\text { gedung }\end{array}$ \\
\hline $\begin{array}{l}\text { Rancangan output: } \\
\text { Laporan LB } 1 \text { dan } \\
\text { LB4 }\end{array}$ & $\begin{array}{l}\text { D isai n o uput } \\
\text { SIMPUS terbatas } \\
\text { pada Iaporan LBI } \\
\text { dan LB4 dan tidak } \\
\text { dapat menghasilkan } \\
\text { Iaporan individual } \\
\text { pelayanan }\end{array}$ & $\begin{array}{l}\text { Rancangan output: } \\
\text { Laporan individual } \\
\text { pelayanan, Laporan } \\
\text { manajemen (Iaporan } \\
\text { pelayanan, pemetaan } \\
\text { penyakit), Laporan } \\
\text { bul anan, Laporan } \\
\text { tri bul anan, dan } \\
\text { Laporan tahunan }\end{array}$ \\
\hline $\begin{array}{l}\text { Dirancang berbasis } \\
\text { web } \\
\text { Multiuser } \\
\text { Integrasi jaringan } \\
\text { komputer terbatas } \\
\text { Tersedia } 1 \text { (satu) } \\
\text { server dan } 1 \text { (satu) } \\
\text { computer client } \\
\text { Tersedia wifi untuk } \\
\text { koneksi internet }\end{array}$ & $\begin{array}{l}\text { Gap Kompleksitas } \\
\text { Teknologi Informasi } \\
\text { Terdapat kekurangan } \\
\text { komputer (jumlah } \\
\text { dan kapasitas) } \\
\text { dan jaringan antar } \\
\text { komputer }\end{array}$ & $\begin{array}{l}\text { Dirancang berbasis } \\
\text { web } \\
\text { Multiuser } \\
\text { Integrasi jaringan } \\
\text { antar komputer } \\
\text { Minimal } 1 \text { server dan } \\
5 \text { komputer client } \\
\text { Tersedia koneksi } \\
\text { internet }\end{array}$ \\
\hline
\end{tabular}

Perbandingan disain SIMPUS dan SIKDA Generik menunjukkan bahwa ada perbedaan konsep mendasar. SIMPUS di di sain berdasarkankonsep tamilytol der artinya kronologi riwayatkesehatan di kelompokkan berdasarkan datakeluarga., sedangkanSI KDA Generik menggunakan konsep indi vidu (Pusdatin, 2011). Kompatibilitas faktor organisasi dapat dilihat pada Tabel 3.

Tabel $3 \mathrm{~K}$ ompatibilitas F aktor Organisasi SIM PUS dengan SIK DA G enerik

\begin{tabular}{lll}
\hline SIMPUS & Gap & SIKDA Generik \\
\hline Perencanaan pe- & Gap Perencanaan: & Perencanaan dengan \\
n g e m b a n g a n & SI M PU S ti dak & masterplan, cetak \\
SIMPUS secara par- & memiliki masterplan & biru, dan roadmap \\
sial pada pelayanan & dan cetak birusistem & \\
dalam gedung yang & informasi & \\
melibatkan vendor & & \\
\hline
\end{tabular}




\begin{tabular}{|c|c|c|}
\hline $\begin{array}{l}\text { Terdapat } 5 \text { orang } \\
\text { pengel ola data } \\
\text { SIMPUS } \\
\text { Terdapat Software } \\
\text { SIMPUS, dan soft- } \\
\text { ware pendukung, } \\
1 \text { server dan } 2 \text { PC, } \\
\text { jaringan terbatas } \\
\text { Terdapat ruang } \\
\text { rekam medis, UPS } \\
\text { dan genset } \\
\text { A nggaran yang } \\
\text { terbatas dari DKK }\end{array}$ & $\begin{array}{l}\text { Gap Sumber Daya } \\
\text { Sumber daya SIM- } \\
\text { PUS: } \\
\text { a K ekur angan } \\
\text { tenaga IT } \\
\text { b K ekur angan } \\
\text { saranapadacaku- } \\
\text { pan sof tware } \\
\text { hardware, dan } \\
\text { jaringan } \\
\text { c. Anggaranterbatas }\end{array}$ & $\begin{array}{l}\text { Pengel ola data dan } \\
\text { teknisi IT } \\
\text { Software SIKDA } \\
\text { generic, software } \\
\text { pendukung, I server } \\
\text { dan } 5 \text { PC, jaringan } \\
\text { komputer } \\
\text { Ruang SIK, supply } \\
\text { listrik dengan ca- } \\
\text { dangan listrik } \\
\text { Pendanaan SIK } \\
\text { meliputi komponen } \\
\text { kebijakan, infra- } \\
\text { struktur, sumber } \\
\text { daya, pemeliharaan, } \\
\text { bahan operasional, } \\
\text { monitoring dan } \\
\text { analisis }\end{array}$ \\
\hline $\begin{array}{l}\text { Pelatihan dilakukan } \\
\text { di DKK dan langsung } \\
\text { di sarana (on thejob) } \\
\text { Materi pel ati han } \\
\text { tentang apl i kasi } \\
\text { S I M P U S, } \\
\text { troubl eshooting, } \\
\text { pelatihan TIK }\end{array}$ & $\begin{array}{l}\text { Gap Pelatihan } \\
\text { Pelatihan SIMPUS } \\
\text { tentang materi } \\
\text { manajemen SIK dan } \\
\text { TIK belumdilakukan }\end{array}$ & $\begin{array}{l}\text { Pelatihan off the job } \\
\text { dan on thejob } \\
\text { Materi pel ati han } \\
\text { tentang komputer } \\
\text { dasar, aplikasi SIK, } \\
\text { troubl eshooting, } \\
\text { pel ati han TIK, } \\
\text { dan knowl edge } \\
\text { management }\end{array}$ \\
\hline $\begin{array}{l}\text { Supervisi dilakukan } \\
\text { secara langsung dari } \\
\text { DKK setahun sekali }\end{array}$ & Gap Supervisi & $\begin{array}{l}\text { Supervisi dilakukan } \\
\text { secara rutin dengan } \\
\text { umpan balik }\end{array}$ \\
\hline
\end{tabular}

Terdapat gap SIMPUS dengan SIKDA Generik yaitu SIMPUS tidak memiliki masterplan, SIMPUS kekurangan sumber daya, pelatihan pengel ola belum mencakup materi manajemen SIK dan teknologi informasi.

\section{Tabel 4 K ompatibilitas F aktor Perilaku SI M PUS dengan SIK DA G enerik}

\begin{tabular}{|c|c|c|}
\hline SIMPUS & Gap & SIK DA G enerik \\
\hline $\begin{array}{l}\text { Permintaan data } \\
\text { dari internal adalah } \\
\text { jumlah kunjungan } \\
\text { pasien } \\
\text { Permintaan data dari } \\
\text { ekstemal adalah LB1 }\end{array}$ & $\begin{array}{l}\text { GapPermintaan Data } \\
\text { Tidak ada permintaan } \\
\text { laporan indivi du } \\
\text { pelayanan }\end{array}$ & $\begin{array}{l}\text { Permintaan laporan } \\
\text { individu pelayanan }\end{array}$ \\
\hline $\begin{array}{l}\text { Pengel ola SIMPUS } \\
\text { memiliki ketrampilan } \\
\text { memeriksa kualitas } \\
\text { data }\end{array}$ & $\begin{array}{l}\text { Tidak ada gap } \\
\text { pada ketrampilan } \\
\text { pemeriksaan kualitas } \\
\text { data }\end{array}$ & $\begin{array}{l}\text { Pengel ol a SIK } \\
\text { memiliki ketrampilan } \\
\text { pemeriksaan kuali- } \\
\text { tas data }\end{array}$ \\
\hline $\begin{array}{l}\text { Satu orang penge- } \\
\text { lola SIMPUS mam- } \\
\text { pu mel akukan } \\
\text { troubl eshooting } \\
\text { sederhana dengan } \\
\text { install ulang software } \\
\text { dan back up data }\end{array}$ & $\begin{array}{l}\text { Gap Kemampuan } \\
\text { memecahkan masa } \\
\text { lah } \\
\text { Pengelola SIMPUS } \\
\text { memiliki kemam- } \\
\text { puan terbatas pada } \\
\text { TIK }\end{array}$ & $\begin{array}{l}\text { Pengel ol a SI K } \\
\text { mampu melakukan } \\
\text { p en y e l es a i a n } \\
\text { masalah pada TIK } \\
\text { (perangkatkomputer } \\
\text { dan jaringan) secara } \\
\text { sistematis }\end{array}$ \\
\hline $\begin{array}{l}\text { Kompetensi penge } \\
\text { Iola SIMPUS: } \\
\text { Dua orang diploma } \\
\text { perekam medis, tiga } \\
\text { orang SMA } \\
\text { Satu orang mengikuti } \\
\text { pelatihan off the job } \\
\text { dan on the job, } 4\end{array}$ & $\begin{array}{l}\text { Gap Kompetensi } \\
\text { Tiga orang pengel ola } \\
\text { perlu peningkatan } \\
\text { pendidikan } \\
\text { Empat orang penge } \\
\text { lola perlu mengi kuti } \\
\text { pelatihan tambahan }\end{array}$ & $\begin{array}{l}\text { Kompetensi penge- } \\
\text { lolaSIK: } \\
\text { Minimal Diploma } \\
\text { kesehatan } \\
\text { Mengikuti pelatihan } \\
\text { SIK, komputer dasar, } \\
\text { TIK, dan manajemen } \\
\text { SIK }\end{array}$ \\
\hline
\end{tabular}

\begin{tabular}{|c|c|c|}
\hline $\begin{array}{l}\text { orang dari pelatihan } \\
\text { on thejob } \\
\text { Pengalaman kerja } \\
\text { Iebih dari } 3 \text { tahun }\end{array}$ & & $\begin{array}{l}\text { Pengamalan kerja } \\
\text { cukup }\end{array}$ \\
\hline $\begin{array}{l}\text { Motivasi pengelola } \\
\text { SIM PU S sudah } \\
\text { cukup baik untuk } \\
\text { aplikasi SIMPUS } \\
\text { lama, perludidukung } \\
\text { pengembangan } \\
\text { SIMPUS }\end{array}$ & $\begin{array}{l}\text { Gap Motivasi } \\
\text { Aplikasi SIM PUS } \\
\text { belum mendukung } \\
\text { peningkatan motivasi } \\
\text { pengelola }\end{array}$ & $\begin{array}{l}\text { Motivasi pengelola } \\
\text { SIK perlu didukung } \\
\text { sarana SIK yang } \\
\text { memadai }\end{array}$ \\
\hline
\end{tabular}

Terdapat gap faktor perilaku SIMPUS dengan SIKDA Generik yaitu tidak ada permintaan data indi vidu pada manaj emen, kemampuan pernecahan masalahTIK dan kompetensi yang terbatas.

\section{PE MBAHASAN}

\section{R ekomendasi Pengembangan SIMPUS untuk Mendukung SIK DA G enerik}

SIMPUS kedepannya perlu dikembangkan secara bertahap. Standar platform dan dataset mengacu pada SIKDA Generik. Berikut rekomendasi pengembangan SIMPUS.

\section{Tabel 5 Rekomendasi Pengembangan SIM PUS untuk M endukung Integrasi SIK DA G enerik}

\begin{tabular}{|c|c|c|c|}
\hline \multicolumn{3}{|c|}{$\begin{array}{l}\text { Alasan Pengembangan SIM PUS } \\
\text { Terintegrasi SIK DA G enerik }\end{array}$} & \multirow{2}{*}{$\begin{array}{l}\text { Rekomendasi } \\
\text { Pengembangan } \\
\text { SIM PUS }\end{array}$} \\
\hline K ebijakan & Permasalahan & Peluang & \\
\hline \multirow{7}{*}{$\begin{array}{l}\text { Kebijakan } \\
\text { pusat ten- } \\
\text { tang in- } \\
\text { tegrasi SIK } \\
\text { Kebijakan } \\
\text { kons e p } \\
\text { family fol- } \\
\text { der dari } \\
\text { DKK }\end{array}$} & \multirow{3}{*}{$\begin{array}{l}\text { Perbedaan kon- } \\
\text { sepSIMPUS ada } \\
\text { lah datakeluarga, } \\
\text { konsep SIKDA } \\
\text { Generik adalah } \\
\text { data individu } \\
\\
\text { Record pel aya- } \\
\text { nan pasien dalam } \\
\text { SI MPUS tidak } \\
\text { terintegrasi }\end{array}$} & \multirow{2}{*}{$\begin{array}{l}\text { Prospek pus- } \\
\text { kesmas men- } \\
\text { jadi BLUD } \\
\text { memung- } \\
\text { kinkan al o- } \\
\text { kasi angga- } \\
\text { ran untuk } \\
\text { SIK lebih } \\
\text { besar }\end{array}$} & $\begin{array}{l}\text { Penerapan single } \\
\text { Identity number } \\
\text { pasien }\end{array}$ \\
\hline & & & $\begin{array}{l}\text { Mengembangkan } \\
\text { family master in- } \\
\text { dex dan patient } \\
\text { master index, } \\
\text { rekam medis } \\
\text { elektronik }\end{array}$ \\
\hline & & \multirow{5}{*}{$\begin{array}{l}\text { Perkemba- } \\
\text { ngan tekno- } \\
\text { logi infor- } \\
\text { masi }\end{array}$} & Mengembangkan \\
\hline & $\begin{array}{l}\text { S I M P U S } \\
\text { ti dak dapat } \\
\text { menghasil kan } \\
\text { laporan } 10 \text { besar } \\
\text { penyakit per }\end{array}$ & & $\begin{array}{l}\text { SIMPUS terin- } \\
\text { tegrasi dengan } \\
\text { pelayanan dalam } \\
\text { gedung dan luar } \\
\text { gedung }\end{array}$ \\
\hline & $\begin{array}{l}\text { wilayah (maping) } \\
\text { dan I aporan } \\
\text { individual pasien }\end{array}$ & & \multirow{2}{*}{$\begin{array}{l}\text { M e n a m b a h } \\
\text { output laporan } \\
\text { untuk manajemen } \\
\text { i nternal dan } \\
\text { eksternal }\end{array}$} \\
\hline & $\begin{array}{l}\text { SIMPUS tidak } \\
\text { mengcover }\end{array}$ & & \\
\hline & $\begin{array}{l}\text { Iaporan LB2- } \\
\text { LB 4, Iaporan } \\
\text { supl emen, LT1- } \\
\text { LT3, dan laporan } \\
\text { keuangan }\end{array}$ & & $\begin{array}{l}\text { Mengembangkan } \\
\text { sistem query data } \\
\text { Mengembangkan } \\
\text { si stem mi grasi } \\
\text { data }\end{array}$ \\
\hline
\end{tabular}


Pengembangan SIMPUS dari faktor teknis, organisasi, dan perilaku berdasarkan rekomendasi adalah sebagai berikut:

1. Faktor Teknis

a Kompleksitas Prosedur

1) Prosedur SIMPUS meliputi modul loket/pendaftaran, pelayanan, apotik, laboratorium, radi ologi, kasir, farmasi, data Iuar gedung, dan pelaporan.

2) Penerapan single ID pasien dapat diterapkan dalam protap dengan prinsip unit numbering syster yaitu satu pasien mendapatkan nomor RM selamanya.

3) Prosedur tetap di buat dua macam yaitu protap untuk mengoperasikan SIMPUS dan protap manual. Protap manual ini diperlukan jika ada gangguan pasokan listrik pada SIMPUS.

b. Kompleksitas Disain SIMPUS

1) Disain SIMPUS yang direkomendasikan adalah terintegrasi antar pelayanan dalam gedung dan luar gedung

2) Terdapat database rekam medis elektronik pasien yang terintegrasi dengan patient master index yang dapat dikelompokkan dalam tamily master index. Rekam medis elektronik ini terdapat data pelayanan/ tindakan dan data obat yang terintegrasi dengan billing system

3) Disain SIMPUS berprinsip pada single ID artinya secara otomatis sistem akan memberikan satu nomor untuk satu pasien. Adanya perbedaan aturan penomoran SIMPUS dan SIKDA Generik dilakukan penyesuaikan nomor RM pasien dalam SIMPUS dengan aturan penomoran pasien dalamSIKDA Generik.

4) Pengembangan ouput SIMPUS untuk memenuhi kebutuhan manajemen internal dan eksternal. Kebutuhan manajemen internal adalah laporan maping penyakit berdasar geogratis, Iaporan kunjungan pasien, dan Iaporan pelayanan. Laporan untuk manajemen eksternal adalah LB1LB4, Iaporan tribulanan, dan LT1-LT3

5) Penambahantasil itas sistemquery data dan migrasi data

a) Sistem yue y

Sistem yuer y adalah sistem untuk menampilkan suatu data dari database dimana mengambil dari tabel-tabel yang ada di database untuk membuat format Iaporan yang dibutuhkan.
Sistem ini akan memberikan kemu dahan bagi pengelolaSIMPUS untuk menyediakan Iaporan sesuai kebutuhan pengguna.

b) Sistemmigrasi data

Salah satu elemen penting untuk mewujudkan integrasi data adalah tersedianya datasource standar dengan melakukan proses ETL (extract, transform and load). Migrasi dataini dil lakukan untuk mentransfer database SIMPUS ke Bank Data Kesehatan

Berikut disain SIMPUS yang dikembangkan seperti pada gambar 5.

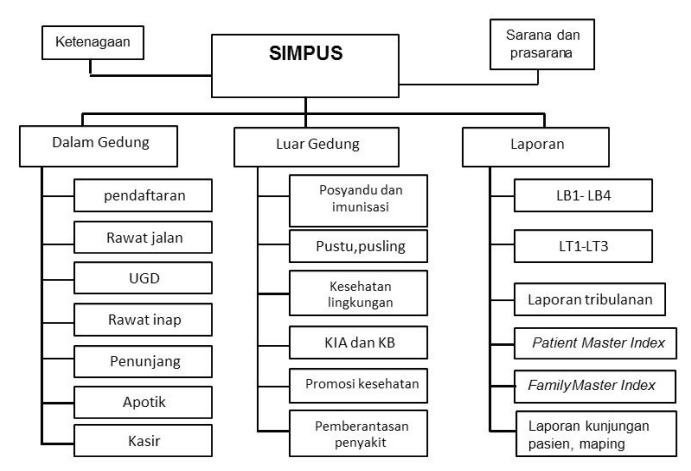

Gambar 2 Rancangan SIMPUS yang dikembangkan

c. Kompl eksitas Teknologi Informasi

1) Hardware

Hardware yang dibutuhkan untuk disain integrasi pelayanan adalah minimal 1 (satu) buah PC server dan 6 (enam) buah PC dient. Server minimal Prosesor Dual Core RAM 1 GB, HDD 250 GB danPC Client minimal Prosesor P 4, RAM 512 MB, HDD 80 GB.(pusdatin, 2011)

Puskesmas induk telah tersedia 2 PC sehingga penambahan hardware yang perlu dilakukan pada pengelolaan SI MPUS di puskesmas induk adal ah empat PC dengan tungsi:

a) Satu PC di pengolahan rekam medis sebagai server

b) Satu PC client ditempatkan pada pendaftaran rawat jalan

c) Satu PC client ditempatkan di pendattaran rawat inap

d) Satu PC client ditempatkan di Klınik urrurrr 
e) Satu PC client ditempatkan di apotik

f) Satu PC client ditempatkan di tata usaha

Penambahan hardware pada pustu pada tahap pengembangan berikutnyajuga perlu dilakukan minimal masing-masing pustu disediakan 1 (satu) PC dengan aplikasi SIMPUS rawatjalan dan modem

2) Software

Software yang di butuhkan adal ah aplikasi SIMPUS yang telah dikembangkan dan software pendukung. Softwarependukung yaitu Microsoft windows, web sever, MySQL server, dan firefox. Dua PC yang telah dimiliki puskesmas telah diinstal sottware pendukung.

3) Jaringan

Komunikasi antar komputer dapat dilakukan dengan wifi LAN (local area nework). Puskesmas telah tersedia wifi LAN dengan satu switch.

Berikutgambaran mekanismekomunikasi data antar pelayanan di puskesmas disajikan pada gambar 3

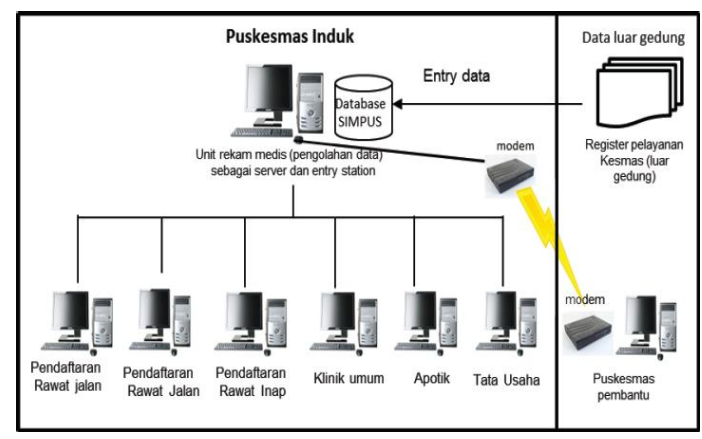

Gambar 3 Mekanisme Komunikasi Data Puskesmas

\section{Faktor Organisasi}

a. Perencanaan

Perencanaan pengembangan SIMPUS dapat dilakukan dengan tahapan:

1) Pembuatan Masterplan

Master plan pada intinya berisi rencana strategis organisasi dalam mengimplementasikan dan membangun sistem intormasi. Master plan berisi pedoman kebutuhan sistem informasi seperti apa yang diperlukan melalui analisis SWOT (strengths, weaknesses, opportunities, and threats). Penyusunan masterplan ini dilakukandi level Dinas Kesehatan Kabupaten Rembang.
2) Perencanaan pengembangan SIMPUS Pengembangan SIMPUS dilakukan dengan mengikuti masterplan yang telah disusun sebelumnya. Pengembangan SIMPUS ini dapat dilakukan di level puskesmas dengan berkoordinasi dengan Dinas Kesehatan Kabur paten Rembang. Puskesmas Kragan 2 sebagai pilot project dapat menjadi puskesmas percontohan untuk pengembangan SIMPUS.

b. Ketersedi aan Sumber Daya

1) Sumber daya manusia

Ada 5 (orang) pengelola SIMPUS dengan pengal aman kerja yang cukup untuk mengel ola SI M PUS yang akan dikembangkan. Tenaga pengelola yang lamadapat didayagunakan untuk mengel olaSI MPUS sebagai al ternatif:

a) Tenaga pendaftaran rawat jalan adalah 2 orang (rekam medis)

b) Tenaga pendaftaran rawat inap adalah 1 orang (rekam medis)

c) Tenaga pengolah data adalah 1 orang (rekam medis)

d) Tenaga input data klinik umum adalah 1 orang (rekam medis)

e) Tenaga input data apotik adalah 2 orang (farmasi dan kasir)

f) Tenaga input data tata usaha adalah 1 orang (TU)

g) Tenaga pengelola data empat pustu adal ah 4 orang (pustu)

2) Infrastruktur SIMPUS

a) Penambahanhardware, software, dan modem

b) Infrastruktur pendukung Penambahan hardware tentunya membutuhkan pasokan listrik. Penambahan UPS per PC diperlukan untuk regulator tegangan dan cadangan listrik. Infrastruktur pendukung Iain adalah penambahan meja kursi untuk penempatan hardware.

3) Anggaran SIMPUS Anggaran yang di butuhkan untuk pengembangan SI MPUS dapat di lakukan dengan penel itian harga pasar. Perhitungan anggaran pengembangan menggunakan metode perhitungan cost benefit. 
Asih Prasetyowati. Anal isis Integrasi Sistem Informasi Manajemen Puskesmas dan Sikda ...

c. Pelatihan

Pelatihan pengelolaan SIMPUS sangat diperlukan untuk mempersiapkan implementasi SIMPUS baru. Pelatihan dapat dilakukan dengan sistem off the job dan on the job. Sasaran pelatihan adal ah pengelola SIMPUS puskesmas induk dan pustu.

d. Supervisi

Supervisi dari manajemen (DKK dan kepala puskesmas) di lakukan dengan cara inspeksi langsung atau melalui laporanIaporan. Oleh karena itu penting bagi manajemen untuk rutin meminta laporan SIMPUS dan memberikan umpan balik. Umpan balik bisa dilakukan dengan memberikan masukan-masukan pada kualitas laporan.

\section{Faktor Perilaku}

a. Permintaan Data

Permintaan data oleh manajemen puskesmas dan DKK berupa laporanlaporan sesuai dengan ketentuan SP2TP. Secara umum laporan yang di buat adalah data aggregate dari register pelayanan. Kebijakan pemerintah pusat tentang integrasi SIK dan standar SIKDA Generik menyebabkan kebutuhan data individual harus dipersiapkan oleh puskesmas (KepmenkesRI, 2011). Hal ini memerlukan pengembangan SIMPUS mengikuti standar data SIKDA Generik. Integrasi data ini perlu dilakukan pada level puskesmas dan level DKK. Rekomendasi kedepannya adalah pengembangan Sistem Informasi DKK.

b. Ketrampilan pemeriksaan data

Pengel ola SIMPUS telah memiliki ketrampilan pemeriksaan data SIMPUS. Metode pemeriksaan data ini belum ditetapkan dalamSOP sehingga diperlukan SOP quality assurance dan qual ity control (pusdatin, 2011)

c. Kemampuan pemecahan masalah

Koordinator rekam medis memiliki ketrampilan menginstal ulang aplikasi dan back up data. Ketrampilan Iain yang dibutuhkan adalah troubleshooting hardware dan jaringan. Ketrampilan ini bisa didapat dengan pelatihan khusus tetapi memerlukan pendampingan dan waktu yang Iama. Direkomendasikan untuk menambah tenaga IT karena sudah memiliki ketrampilan IT dasar.

d. Kompetensi dan tugas SIK Kompetensi yang dimiliki pengelola SIMPUS sudahmencukupi untuk SIMPUS lama Jika SIMPUS akan dikembangkan makadiperlukan pengembanganSDM yang ada. Perlu direncanakan pengembangan SDM dengan peningkatan pendidikan dan pelatihan. Pendidikan minimal Diploma Sistem Informasi dan mengikuti pelatihanpelatihan SIK (Pusdatin, 2011)

e. Motivasi

Motivasi merupakan dorongan dari pengelola SIMPUS agar terus aktif dal am mengumpulan data, mengolah, dan menyajikan data yang berkualitas (Hasibuan, 2003). Motivasi ditingkatkan dengan pengembangan SIMPUS sesuai kebutuhan.

\section{SIM PULAN}

1. Integrasi SIMPUS dan SIKDA Generik Integrasi terbentur pada kesenjangan antara SIMPUS dan SIKDA Generik yaitu konsep family pada SIMPUS dengan konsep individu pada SIKDA Generik, SIMPUS tidak dapat menghasilkan laporan individu pelayanan, dan tidak adanya masterplan pengembangan SIMPUS

2. Rekomendasi Pengembangan SIMPUS untuk mendukung integrasi data dengan SIKDA Generik adalah penerapan singleidentity number pasien, mengembangkanfamily master index dan patient master index, mengembangkan rekam medis elektronik pasien, mengembangkan SIMPUS terintegrasi dengan pelayanan dalam gedung dan luar gedung, menambah output laporan untuk manajemen internal dan eksternal, mengembangkan sistem query data, dan mengembangkan sistem migrasi data.

\section{DAFTAR PUSTAKA}

Aqil, Anwer. 2009. Lippeveld. Hozumi. PRISM Framework : A ParadigmShift for Designing, Strengthening and Evaluating Routine Health Information Systems. Oxford J ournals Health Policy and Planning. May; 24(3):217-228. Tersedia dalamURL: http://www.ncbi.nlmnih. gov/pmc/articles/PMC2670976. . Diakses pada tanggal 23/5/2015, 11.50 
J urnal Manajemen I nformasi Kesehatan Indonesia Vol . 4 No.2 Oktober 2016

ISSN: 2337-6007 (online); 2337-585X (Printed)

Departemen Kesehatan RI. Sistem Kesehatan Nasional Tahun2009. Tersedia dalam URL: http://www.depkes.go.id/downloads/ SK N\%20final .pdf.Diakses pada tanggal 25/2/2015, 12:40.

Hasi buan, Malayu. 2007. Manajemen Sumber Daya Manusia.Edisi Revisi. Jakarta: PT Bumi Aksara

J ogiyanto. 2008. Sistem Teknologi Informasi . Yogyakarta : PenerbitANDI

Kementrian Kesehatan RI. 2011. Pedoman Sistem Informasi Kesehatan Tahun 2011. URL:http:// mediainfo.sourceforge.net/, diakses pada tanggal 16/5/2015, 11:04

Kementrian Kesehatan RI. 2011. Roadmap Sistem Informasi Kesehatan 2011-2014. Tersedia

dalam : http://www.depkes.go.id/downl oads/ Roadmap\%20SIK final.pdf. Diakses pada tanggal 06/4/2015, 04:30

Pusat data dan Informasi. 2012. SI KDA Generik. URL: http://www.sikda.depkes.go.id/. Diakses pada tanggal 20/5/2015, 6:50

Pusat Data dan Informasi . 2012 Panduan Penggunaan SIKDA Generik Puskesmas. URL:http:// mediainfo.sourceforge.net/. Diakses pada tanggal 6/4/2013, 4:07

Pusat Data dan Informasi. 2013. SIKDA GenerikDataset Minimal. URL: http://www.sikda. depkes.go.id/doc/. Diakses pada tanggal 21/5/2013, 3:51.

Y in, Robert K. 2011. Studi Kasus Desain dan Metode. Jakarta: PT Raja Grafindo Persada. 